\title{
Inequality in Indonesia: What can we learn from top incomes?
}

\author{
Andrew Leigh ${ }^{\mathrm{a}, *}$, Pierre van der Eng ${ }^{\mathrm{b}}$ \\ ${ }^{a}$ Research School of Social Sciences, ANU College of Arts and Social Sciences, Australian National University, Australia \\ ${ }^{\mathrm{b}}$ School of Management, Marketing and International Business, ANU College of Business and Economics, Australian National University, Australia
}

\section{A R T I C L E I N F O}

\section{Article history:}

Received 3 July 2008

Accepted 16 September 2008

Available online 25 September 2008

\section{JEL classification:}

$\mathrm{H} 24$

N35

015

\section{Keywords:}

Inequality

Top incomes

Personal income taxation

Indonesia

\begin{abstract}
A B S T R A C T
Using taxation and household survey data, this paper estimates top income shares for Indonesia during 1920-2004. Our results suggest that top income shares grew during the 1920s and 1930 s, but fell in the post-war era. We observe a sharp rise in top income shares during the late1990s, coinciding with the 1997-98 economic crisis. Where comparable data are available, top income shares in Indonesia are generally higher than in other countries, a finding that is at odds with the view that Indonesia is a relatively egalitarian society. This suggests that top income shares may provide a more complete picture of developing country inequality in comparative perspective.
\end{abstract}

(c) 2008 Elsevier B.V. All rights reserved.

\section{Introduction}

Academic literature on income distribution in Indonesia often indicated that income inequality has been relatively low as a consequence of the 'pro poor' policies pursued by its government. For example, a two-page discussion of Indonesia's economic performance over recent decades in the World Development Report 2006 used the phrase 'pro-poor' 12 times (World Bank, 2005b: 126-127; see also Ragayah, 2005; Timmer, 2004, 2005; World Bank, 2005a). Yet it has been argued that this may be a misconception, arising from significant difficulties in interpreting the available income and expenditure survey data for Indonesia (Cameron, 2002).

Here, we approach the issue through the lens of top income shares. Building on recent studies for other countries, analysing newfound historical data, and comparing our results with similar data for other countries, we estimate top income shares for the world's fourth most populous nation, and one of Asia's largest economies. We offer an assessment of changes in the share of top

\footnotetext{
is This paper presents some results that are explored in more detail in Leigh and van der Eng (in press). We are grateful to Anggito Abumanyu (Economic, Financial and International Cooperation Analysing Board BAPPEKI, Ministry of Finance of Indonesia) and Robert Pakpahan (Directorate General of Taxation, Ministry of Finance of Indonesia) for help in obtaining taxation data for recent years, to Anne Booth and Terry Hull for advice on constructing our population and income control totals, to Sophie Holloway and Stephen Gray for help obtaining survey data, to Alicia Paul and Michael Leigh for assistance with survey data definitions, to Gweneth Leigh for assistance in tabulating taxation data for the pre-war era, and to Daniel Suryadarma and Thee Kian Wie for advice on constructing our top tax rate series. Susanne Schmidt, Elena Varganova and Yogi Vidyattama provided outstanding research assistance. Anthony Atkinson, Gavin Jones, Peter Lindert, Chikako Yamauchi, participants at the XIV International Economic History Congress, and a seminar at the Australian National University provided valuable comments on earlier drafts, as did Thomas Piketty and four anonymous referees. All errors are ours.

* Corresponding author.

E-mail addresses: andrew.leigh@anu.edu.au (A. Leigh), pierre.vandereng@anu.edu.au (P. van der Eng).

URLs: http://econrsss.anu.edu.au/ aleigh/ (A. Leigh), http://ecocomm.anu.edu.au/people/pierre.vandereng (P. van der Eng).
} 
income earners in Indonesia on the basis of income tax data for 1920-39 and 1990-2003, augmented by household income data from the country's national socio-economic survey for 1982-2004.

\section{Estimating top income shares}

The general methodological issues surrounding the use of taxation data to estimate top income shares have been well canvassed by Atkinson (2007). In essence, our approach involves using external control totals for both the adult population and total personal income, and interpolating top income shares using tabulated income taxation data. In Indonesia, as in other countries, those with incomes below a certain threshold were not liable for income tax. Our control totals are the total population that would have paid income tax if such thresholds did not apply, and the total personal income that would have been declared if such thresholds did not apply. For all years in our sample, the income unit in Indonesia is the household.

Our estimates of top income shares in Indonesia are based on three sources. The first are income taxation data compiled at the Ministry of Finance of colonial Indonesia for 1920-1939, and published annually in the statistical yearbooks. During this period, all

Table 1

Top Income Shares in Indonesia, 1920-39 and 1982-2004

\begin{tabular}{|c|c|c|c|c|c|c|c|}
\hline Year & Top $10 \%$ & Top 5\% & Top 1\% & Top $0.5 \%$ & Top $0.1 \%$ & Top $0.05 \%$ & Top $0.01 \%$ \\
\hline \multicolumn{8}{|c|}{ Using income taxation data } \\
\hline 1920 & & & & 6.92 & 3.70 & 2.73 & 1.39 \\
\hline 1921 & & & 11.82 & 10.08 & 5.54 & 4.15 & 2.21 \\
\hline 1922 & & & 14.28 & 11.53 & 5.35 & 3.72 & 1.69 \\
\hline 1923 & & & 14.81 & 11.99 & 5.69 & 4.04 & 1.93 \\
\hline 1924 & & & 14.42 & 11.62 & 5.67 & 4.06 & 1.97 \\
\hline 1925 & & & 14.19 & 11.42 & 5.65 & 4.01 & 1.91 \\
\hline 1926 & & & 15.00 & 12.08 & 5.97 & 4.30 & 2.04 \\
\hline 1927 & & & 15.52 & 12.41 & 5.98 & 4.24 & 1.94 \\
\hline 1928 & & & 16.38 & 13.04 & 6.14 & 4.30 & 1.93 \\
\hline 1929 & & & 16.71 & 13.31 & 6.32 & 4.45 & 1.92 \\
\hline 1930 & & & 16.64 & 13.08 & 5.87 & 4.02 & 1.67 \\
\hline 1931 & & 30.57 & 20.03 & 15.65 & 6.77 & 4.53 & 1.78 \\
\hline 1932 & & 32.62 & 21.13 & 16.57 & 7.02 & 4.62 & 1.74 \\
\hline 1933 & & 32.83 & 21.55 & 17.01 & 7.18 & 4.68 & 1.72 \\
\hline 1934 & & 31.82 & 21.51 & 17.02 & 7.22 & 4.69 & 1.68 \\
\hline 1935 & & & & 15.82 & 6.81 & 4.45 & 1.60 \\
\hline 1936 & & & & 15.99 & 6.93 & 4.52 & 1.63 \\
\hline 1937 & & & & 14.64 & 6.56 & 4.38 & 1.69 \\
\hline 1938 & & & 19.80 & 15.84 & 7.24 & 4.90 & 2.00 \\
\hline 1939 & & & 19.87 & 15.83 & 7.03 & 4.68 & 1.83 \\
\hline \multicolumn{8}{|c|}{ Using household survey data } \\
\hline 1982 & 32.64 & 20.85 & 7.17 & 4.60 & 1.80 & 1.21 & 0.58 \\
\hline 1987 & 36.48 & 24.12 & 7.99 & 4.68 & 1.23 & 0.61 & 0.28 \\
\hline 1990 & 36.11 & 23.16 & 8.05 & 5.28 & 1.61 & 0.95 & 0.35 \\
\hline 1993 & 39.94 & 26.07 & 9.10 & 5.85 & 2.04 & 1.33 & 0.38 \\
\hline 1996 & 39.37 & 25.30 & 9.69 & 6.59 & 2.06 & 1.38 & 0.37 \\
\hline 1998 & 36.22 & 24.92 & 12.42 & 9.87 & 5.93 & 4.93 & 2.17 \\
\hline 1999 & 37.47 & 26.39 & 13.65 & 10.86 & 6.20 & 4.68 & 1.87 \\
\hline 2000 & 38.45 & 27.25 & 13.82 & 11.11 & 6.94 & 5.29 & 2.25 \\
\hline 2001 & 39.53 & 28.42 & 15.52 & 12.63 & 5.26 & 3.20 & 1.35 \\
\hline 2002 & 36.38 & 23.40 & 10.47 & 7.93 & 4.05 & 3.21 & 1.58 \\
\hline 2003 & 34.58 & 24.36 & 9.76 & 7.26 & 3.59 & 2.54 & 0.91 \\
\hline 2004 & 34.76 & 22.03 & 8.46 & 5.89 & 2.12 & 1.29 & 0.47 \\
\hline \multicolumn{8}{|c|}{ Using income taxation data } \\
\hline 1990 & & & & & & 1.01 & 0.69 \\
\hline 1991 & & & & & & 0.90 & 0.58 \\
\hline 1992 & & & & & & 1.04 & 0.69 \\
\hline 1993 & & & & & & 1.02 & 0.66 \\
\hline 1994 & & & & & & 1.02 & 0.67 \\
\hline 1995 & & & & & & 0.89 & 0.55 \\
\hline 1996 & & & & & & 0.91 & 0.56 \\
\hline 1997 & & & & & & 0.94 & 0.59 \\
\hline 1998 & & & & & & 0.80 & 0.54 \\
\hline 1999 & & & & & & 0.84 & 0.58 \\
\hline 2000 & & & & & & 1.05 & 0.78 \\
\hline 2001 & & & & & & 1.20 & 0.81 \\
\hline 2002 & & & & & 1.47 & 1.26 & 0.75 \\
\hline 2003 & & & & & 1.34 & 1.10 & 0.61 \\
\hline
\end{tabular}

Note: Survey data are not available annually before 1998 . 


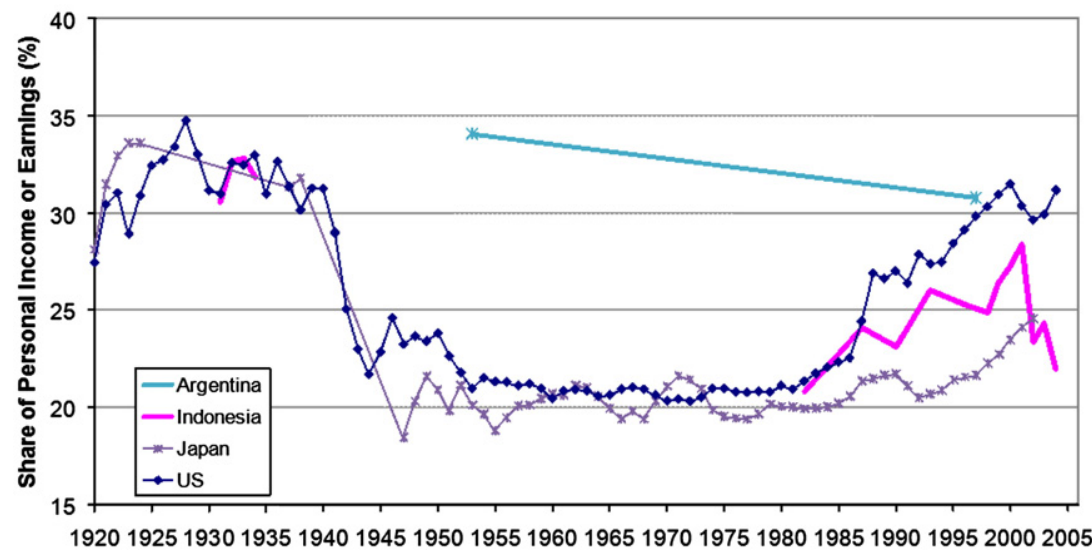

Fig. 1. Income Share of the Top 5\% in Argentina, Indonesia, Japan, and the United States.

Sources: Argentina, Alvaredo (2007); Indonesia, authors' calculations; Japan, Moriguchi and Saez (2008); the United States, Piketty and Saez (2003, 2006).

individual income earners with incomes above the tax threshold (initially f120) were required to pay tax. ${ }^{1}$ However, farmers in Indonesia's main island of Java who were liable for land tax (landrente) were exempted from income tax. This was also the case in some other parts of the country, where the land tax was introduced during the 1920s-30s. Consequently, many ethnic Indonesians in Java were exempted from income tax, because they had income from land. We adjust our control totals accordingly.

Our second set of personal income taxation data cover the period 1990-2003, and were especially extracted for us in 2005 at the Directorate General of Taxation of the Ministry of Finance in Jakarta. So far as we are aware, we are the first to use these particular data. An advantage of 1990-2003 taxation data is that they are highly disaggregated. However, a disadvantage of these data is that we are only able to identify the very top taxpayers. In addition, since taxpayers with only salary income are not required to file a return, our results assume that all those with incomes in the top $0.5 \%$ of the distribution filed a return; either because they wished to seek deductions, or because they had non-salary income.

The third data source is the Susenas household survey. This has been frequently used for estimating expenditure inequality, but only rarely for analysing the distribution of income. We were able to obtain a relatively consistent income definition for 12 years between 1982 and 2004. The sample size is around 30,000 households for 1982-96, and around 80,000 households thereafter. It should be noted that the income definition in the Susenas differs from that in the taxation data, being total household employee earnings. We assumed that the household samples were representative of the population, so that it was not necessary to use external control totals.

Our estimated top income shares are presented in Table 1. In 1921, the richest percentile group held 12\% of total income. We observe sharp increases in the share of the richest 1\% during 1921-23 and 1930-32. In both cases, the increases may have been caused by significant reductions in the incomes of farm households relative to those of non-farm households, caused by drastic falls in the price of farm-produced export commodities, such as copra and rubber, in both the early 1920s and early 1930s. Most export commodities were produced by farmers outside Java who were not exempted from income tax. In the early 1920 s, the price fall was in part a correction from a situation of very high commodity prices during and immediately after World War I. The price fall in the early 1930s was a consequence of oversupply in and reduced access to commodity export markets, combined with increased competition from imported commodities, particularly rice. While high income salary earners were to a degree shielded from the effects of these commodity price falls, small-scale farmers had few choices to evade them, apart from returning to subsistence production. In 1933-34, the richest $1 \%$ held $22 \%$ of total income. By $1938-39$, their share had fallen slightly to $20 \%$ of total income.

We then have a four-decade break in our series. When we resume with the 1982 survey data, we find the income share of the richest $1 \%$ to be lower - around $7 \%$ (note that our income measure also differs, now being employee earnings). Over the next two decades, the top $1 \%$ share fluctuated between 7\% and 16\%. From 1996 to 1998, the top percentile group's share rose from 10\% to 12\%, suggesting that the sharp 1997-98 economic crisis increased the concentration of income at the top of the distribution. For the years in which we have both taxation and survey estimates of top income shares, the former tend to be lower.

How do these estimates compare with those from other countries? For this purpose, we chose India (Banerjee and Piketty, 2005) and Japan (Moriguchi and Saez, 2008), the two other Asian countries for which top income shares are available over a long time span; Argentina (Alvaredo, 2007), being the only Latin American country for which we were able to obtain long-run top income estimates; and the United States (Piketty and Saez, 2003, 2006), since it provides a familiar benchmark for many readers. In the case of Argentina and the United States, the estimates are based on households, while the estimates for India and Japan are based on individuals. The estimates for India, Japan, and the United States are derived from taxation data, while those for Argentina are based upon both taxation and survey data.

Fig. 1 compares the top 5\% share in Indonesia with that in Argentina, Japan, and the United States (the top 5\% share is unavailable for India). During the early-1930s, the top 5\% share was very similar in all three countries. In the 1980s and 1990s, the top vingtile share in Indonesia rose more rapidly than in Japan, though less rapidly than in the United States. In the early-2000s, the Indonesian

\footnotetext{
1 The currency unit in colonial Indonesia was the guilder $(f)$, which was renamed rupiah (Rp) after Indonesia's independence.
} 


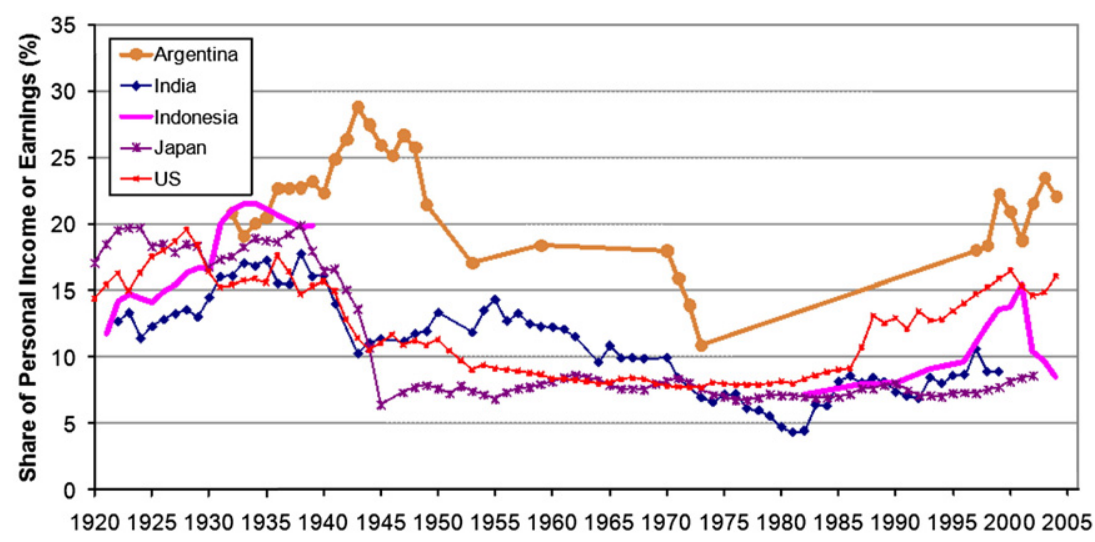

Fig. 2. Income Share of the Top $1 \%$ in Argentina, India, Indonesia, Japan, and the United States.

Sources: Argentina, Alvaredo (2007); India, Banerjee and Piketty (2005); Indonesia, authors' calculations; Japan, Moriguchi and Saez (2008); the United States, Piketty and Saez $(2003,2006)$.

top 5\% share fell; leaving it closer to the Japanese estimate than the United States estimate at the very end of the period. There are only two observations of the top $5 \%$ share for Argentina, both significantly higher than for other countries in the same years.

Fig. 2 charts the top $1 \%$ share. In Indonesia, India, and the United States, the series follows a similar trajectory, peaking in the 1920s or 1930s, falling in the middle decades of the twentieth century, and rising in the 1980s and 1990s (though not to the heights of the early decades). A similar pattern holds for Argentina, though the peak is in the 1940s. In the 1980s and 1990s, the share of the top percentile group was slightly higher in Indonesia than in India and Japan (and much higher during the 1997-98 crisis). The share of the richest 1\% in Indonesia was lower than in Argentina and the United States during most of the twentieth century, although the level of top income inequality in Indonesia exceeded the level in both Argentina and the United States in the 1930s. As noted above, the high level of inequality in Indonesia in the 1930s is possibly caused by the fact that agricultural producers suffered from the downturn in the terms of trade of agricultural commodities vis-à-vis non-agricultural producers. In the United States, economic regulation and protection may to a degree have prevented a similarly sharp drop in agricultural incomes relative to non-agricultural incomes.

\section{Conclusion}

Although estimates from taxation and survey data have their limitations, both suggest that top income shares in Indonesia have been relatively high over the course of the twentieth century. This finding may surprise some readers, as it contradicts the common 'growth with equity' understanding of Indonesia's growth experience since the 1960s. Yet our results are also bolstered by evidence from other sources. For example, top wealth shares appear to be larger in Indonesia than in many other countries, whether one uses data from wealth surveys (Davies et al., 2008), or the Forbes rich lists (Leigh and van der Eng, in press). This suggests that there is much to be learned from studying top incomes in order to better understand inequality in developing nations.

\section{Appendix A. Supplementary data}

Supplementary data associated with this article can be found, in the online version, at doi:10.1016/j.jpubeco.2008.09.005.

\section{References}

Alvaredo, F., 2007. The Rich in Argentina over the Twentieth Century: From the Conservative Republic to the Peronist Experience and beyond 1932-2004. Paris School of Economics Working Paper 2007-02.

Atkinson, A.B., 2007. Measuring top incomes: methodological issues. In: Atkinson, A., Piketty, T. (Eds.), Top Incomes over the Twentieth Century: A Contrast Between Continental European and English Speaking Countries. Oxford University Press, Oxford, pp. 18-42.

Banerjee, A., Piketty, T., 2005. Top Indian Incomes, 1922-2000. The World Bank Economic Review 19, 1-20.

Cameron, L., 2002. Growth with or without equity? The distributional impact of Indonesian development. Asian-Pacific Economic Literature 16 (2), 1-17.

Davies, J.B., Sandstrom, S., Shorrocks, A., Wolff, E.N., 2008. The World Distribution of Household Wealth. WIDER Discussion Paper 2008/03. Helsinki: UNU-WIDER.

Leigh, A., van der Eng, P., in press. Top incomes in Indonesia, 1920-2004. In: Atkinson, A., Piketty, T. (Eds.), Top Incomes Over the Twentieth Century: Volume II - A Global Perspective. Oxford University Press, Oxford.

Moriguchi, C., Saez, E., 2008. The evolution of income concentration in Japan, 1885-2002: evidence from income tax statistics. Review of Economics and Statistics 90 (4), 713-734.

Piketty, T., Saez, E., 2003. Income Inequality in the United States, 1913-1998. Quarterly Journal of Economics 118 (1), 1-39.

Piketty, T., Saez, E., 2006. Income Inequality in the United States. Tables and Figures updated to 2004 in Excel format, http://emlab.berkeley.edu/users/saez/.

Ragayah, H.M.Z., 2005. Income distribution in East Asian developing countries: recent trends. Asian-Pacific Economic Literature 19 (1), $36-54$.

Timmer, C.P., 2004. The road to pro-poor growth: The Indonesian experience in regional perspective. Bulletin of Indonesian Economic Studies 40 (2), $177-207$.

Timmer, C.P., 2005. Operationalizing Pro-Poor Growth: Country Study for the World Bank, Indonesia. Unpublished manuscript, http://siteresources.worldbank.org/ INTPGI/Resources/342674-1115051237044/oppgindonesiaMay2005.pdf.

World Bank, 2005a. Pro-Poor Growth in the 1990s, Lessons and Insights from 14 Countries: Operationalizing Pro-Poor Growth Research Program. The World Bank, Washington DC.

World Bank, 2005b. World Development Report 2006. The World Bank, Washington DC. 